\section{Winter-applied Glyphosate Effects on Spring Green-up of Zoysiagrasses and 'Yukon' Bermudagrass in a Transition Zone}

\author{
Filippo Rimi ${ }^{1}$, Stefano Macolino ${ }^{1,3}$, and Bernd Leinauer ${ }^{2}$
}

ADDITIONAL INDEX WORDs. Zoysia matvella, turfgrass, sod, postemergence herbicide, winter dormancy, turf management

SUMMARY. In transitional environments, turf managers and sod producers of warmseason grasses face the issue of winter annual weeds that can dominate dormant turf stands through the winter until late spring. The use of glyphosate to control weeds in dormant bermudagrass (Cynodon dactylon) has been well documented, but information is lacking about its effect on spring green-up of other warm-season grasses. A field study was conducted on two commercial sod farms in northern Italy (Expt. 1) to evaluate the effects of glyphosate applied on two different winter dates on weed control and spring green-up of 'Zeon' manilagrass (Zoysia matvella). A second study was carried out at the experimental agricultural farm of Padova University (Expt. 2) to assess the effects of a winter application of glyphosate on weed control and spring green-up of 'Yukon' bermudagrass and 'Companion' zoysiagrass (Zoysia japonica). Each experiment was conducted from Jan. to June 2011 , and glyphosate was applied at $1.1 \mathrm{~kg} \cdot \mathrm{ha}^{-1}$ on 8 and $21 \mathrm{Feb}$. in Expt. 1 and on $8 \mathrm{Feb}$. in Expt. 2. Spring recovery was evaluated by periodical visual ratings of green turf cover and by collecting normalized difference vegetation indices (NDVIs). Weed injury was visually evaluated on all plots 7 weeks after the 8 Feb. glyphosate application. The visual ratings of green cover were strongly and positively correlated with NDVI measurements. Glyphosate applied in February as a single treatment effectively controlled winter weeds in 'Zeon' manilagrass (Expt. 1) and 'Yukon' bermudagrass (Expt. 2) without negatively affecting spring green-up. In contrast, spring green-up of 'Companion' zoysiagrass (Expt. 2) was delayed by the application of glyphosate.

$\mathrm{O}$ ver the last few years the use of warm-season grasses, such as bermudagrass and zoysiagrass, has rapidly increased in the Mediterranean countries of Europe (Croce et al., 2001; Volterrani et al., 1997). These species are also becoming very popular in the sod production industry because of their good sod-forming characteristics. The primary concern of sod producers is to obtain an adequate quality for harvest in the shortest possible period with minimal inputs. However, the time necessary to obtain a sod ready for harvest depends on grass

\footnotetext{
The authors thank Rossana Sallenave and Umberto Ziliotto for their advice and review of the manuscript. The technical assistance of Michele Bertoni is also gratefully acknowledged. Appreciation is given to the sod farms Fedrigo (Verona, Italy) and Torrani (Varese, Italy) whose turf fields were used for this study. This research was supported by the Italian Ministry of Instruction, University and Research (MIUR).

${ }^{1}$ Department of Environmental Agronomy and Crop Production, University of Padova, viale dell'Università 16, Agripolis 35020, Legnaro, Padova, Italy

${ }^{2}$ Department of Extension Plant Sciences, New Mexico State University, N230 Skeen Hall, Las Cruces, NM 88003

${ }^{3}$ Corresponding author. E-mail: stefano.macolino@
} unipd.it. species, cultivar, environmental conditions, and cultural practices (Beard, 1973; McCalla et al., 2008). Highquality sod is expected to have full green color, no weeds, in addition to high density and uniformity, and other technical traits, such as strength for transplanting (McCalla et al., 2008).

Cool-season grasses are generally seed propagated and a harvestable sod can be produced after $\approx 6$ months by adding rhizomatous species, such as kentucky bluegrass (Poa pratensis), to the seed mixture or by using a synthetic netting (Carrow and Sills, 1980).
In contrast, several warm-season grasses are commonly established by sprigging or plugging and can be easily reestablished by regrowth from rhizomes (Christians, 1998). Under restrictive climate conditions, the time required to produce a sod of warm-season species may exceed the period of time in which temperatures are in the optimum range for growth (Beard, 1973). In transitional environments, zoysiagrass often needs longer than one growing season to establish (Severmutlu et al., 2011 ) and such slow growth rates are the main reason for choosing sodding over seeding as the method of establishment. Studies conducted on seeded cultivars and vegetative hybrids of bermudagrass suggest that a minimum of 16 weeks are needed to produce a marketable sod (McCalla et al., 2008; Mitchell and Dickens, 1979), leading to transplanting in late summer or autumn under suboptimal conditions for rooting. To avoid these issues, warm-season turfgrass sod is often harvested at the onset of the second or third growing season, after reaching full spring green-up.

One of the major problems for producers of warm-season sod are winter annual weeds, which germinate in early fall and reduce quality of turfgrasses emerging in from dormancy in spring (Johnson, 1980). Postemergence herbicides are used extensively to kill winter annual weeds in warmseason turfgrasses, and application timing may optimize weed control. However, application timing of nonselective herbicides is critical as spring green-up can be inhibited (Johnson, 1977; Johnson and Burns, 1985; Johnson and Ware, 1978). Postemergence nonselective herbicides such as glyphosate and paraquat effectively control annual weeds and cause no injury to bermudagrass when applied on dormant turf during the winter (Johnson

\begin{tabular}{llll}
\hline $\begin{array}{l}\text { Units } \\
\text { To convert U.S. to SI, } \\
\text { multiply by }\end{array}$ & U.S. unit & SI unit & $\begin{array}{l}\text { To convert SI to U.S., } \\
\text { multiply by }\end{array}$ \\
\hline 0.3048 & $\mathrm{ft}$ & $\mathrm{m}$ & 3.2808 \\
0.0929 & $\mathrm{ft}^{2}$ & $\mathrm{~m}^{2}$ & 10.7639 \\
9.3540 & gal $/ \mathrm{acre}$ & $\mathrm{L} \cdot \mathrm{ha}^{-1}$ & 0.1069 \\
25.4 & inch $(\mathrm{es})$ & $\mathrm{mm}$ & 0.0394 \\
0.0418 & langley(s) & $\mathrm{MJ} \cdot \mathrm{m}^{-2}$ & 23.9006 \\
1.1209 & $\mathrm{lb} / \mathrm{acre}$ & $\mathrm{kg} \cdot \mathrm{ha}^{-1}$ & 0.8922 \\
305.1517 & $\mathrm{oz} / \mathrm{ft}^{2}$ & $\mathrm{~g} \cdot \mathrm{m}^{-2}$ & 0.0033 \\
7.4892 & $\mathrm{oz} / \mathrm{gal}$ & $\mathrm{g} \cdot \mathrm{L}^{-1}$ & 0.1335 \\
1 & $\mathrm{ppm}$ & $\mathrm{mg} \cdot \mathrm{kg}^{-1}$ & 1 \\
6.8948 & $\mathrm{psi}$ & $\mathrm{kPa}$ & 0.1450 \\
$\left({ }^{\circ} \mathrm{F}-32\right) \div 1.8$ & ${ }^{\circ} \mathrm{F}$ & ${ }^{\circ} \mathrm{C}$ & $\left(1.8 \times{ }^{\circ} \mathrm{C}\right)+32$ \\
& & &
\end{tabular}


1980, 1984). However, these herbicides may delay spring green-up of bermudagrass if they are applied when the grass has physiologically transitioned out of winter dormancy (Fagerness et al., 2002; Johnson, 1984).

A delay in spring green-up may shift the date of harvest, narrowing the time frame available for a reestablishment of sod. Based on the requirements of sod producers, weed control should be tailored according to local environmental conditions (Breuninger and Schmidt, 1981; Johnson, 1976). The use of glyphosate during the cooler months is commonly recommended for zoysiagrass and manilagrass turf (Tae, 2005; Velsor et al., 1989). Despite the suggested winter application of glyphosate on zoysiagrasses, research is limited that document the effects of this cultural practice on spring greenup. Experiments were conducted to evaluate the effects of glyphosate application timing on three turfgrass species on spring transition.

\section{Materials and methods}

EXPERIMENT 1. This study was conducted from Jan. to June 2011 at two commercial sod farms in northern Italy: Somma Lombardo (lat. $45^{\circ} 4 \mathrm{I}^{\prime} \mathrm{N}$, long. $8^{\circ} 4 \mathrm{l}^{\prime} \mathrm{E}$, elevation $256 \mathrm{~m}$ ) and Sommacampagna (lat. $45^{\circ} 18^{\prime} \mathrm{N}$, long. $11^{\circ} 01^{\prime} \mathrm{E}$, elevation $\left.30 \mathrm{~m}\right)$. The soil at Somma Lombardo site was a sandy loam ( $5 \%$ clay, $29 \%$ silt, $66 \%$ sand) with a $5.1 \%$ organic matter $(\mathrm{OM})$ content, a $\mathrm{pH}$ of $5.1,6 \mathrm{mg} \cdot \mathrm{kg}^{-1}$ of available phosphorus $(\mathrm{P})$, and $36 \mathrm{mg} \cdot \mathrm{kg}^{-1}$ of exchangeable potassium $(\mathrm{K})$. The soil at the Sommacampagna site was a loamy sand ( $9 \%$ clay, $19 \%$ silt, $72 \%$ sand) with a $1.8 \% \mathrm{OM}$, a $\mathrm{pH}$ of $8.1,18$ $\mathrm{mg} \cdot \mathrm{kg}^{-1} \mathrm{P}$, and $218 \mathrm{mg} \cdot \mathrm{kg}^{-1} \mathrm{~K}$. Both locations have a humid subtropical climate with a bimodal precipitation pattern (Table 1 ) and are similar to plant hardiness zone 8 (U.S. Department of Agriculture, 1990).

The manilagrass cultivar Zeon was established at both locations in July 2009 by planting $25-\mathrm{mm}$-diameter plugs at a rate of 18 plugs $/ \mathrm{m}^{2}$. During the establishment phase, irrigation was provided at a rate of $5 \mathrm{~mm} \cdot \mathrm{d}^{-1}$. Following establishment, plots were mowed two times per week with a reel mower set at a height of $27 \mathrm{~mm}$, with clippings returned. A slow-release fertilizer $(16 \mathrm{~N}-0 \mathrm{P}-12.5 \mathrm{~K})$ was applied monthly to the Somma Lombardo site from May to August at the rate of $5 \mathrm{~g} \cdot \mathrm{m}^{-2}$ nitrogen $(\mathrm{N})$. At the Sommacampagna location, a slow-release fertilizer $(16 \mathrm{~N}-2 \mathrm{P}-8.3 \mathrm{~K})$ was applied in May, June, and August at the rate of $6.6 \mathrm{~g} \cdot \mathrm{m}^{-2} \mathrm{~N}$.

In Dec. 2010 , nine plots $(2 \times 3 \mathrm{~m})$ were established at each of the two research sites. Treatments were randomly assigned to the plots arranged in a randomized complete block design at each location. Treatments consisted of: 1) glyphosate at $1.1 \mathrm{~kg} \cdot \mathrm{ha}^{-1}$ on 8 Feb. 2011,2) glyphosate at 1.1 $\mathrm{kg} \cdot \mathrm{ha}^{-1}$ on $21 \mathrm{Feb} .2011$, and 3) untreated control. Each treatment was replicated three times. The rate and dates of application were chosen according to typical management practices used in these areas with regard to winter control of annual bluegrass (Poa annua). Daily growing degree days
(GDD) were calculated beginning on 1 Jan. 2011 for the applications of glyphosate for both locations, using $5{ }^{\circ} \mathrm{C}$ as a base temperature (Patton et al., 2004; Schiavon et al., 2011; Severmutlu et al., 2011). The accumulated GDD were as follows: Somma Lombardo, 1 Jan. to 8 Feb. $=52$ GDD, 1 Jan. to 21 Feb. $=87$ GDD; Sommacampagna, 1 Jan. to 8 Feb. $=36$ GDD, 1 Jan. to 21 Feb. $=73$ GDD. The glyphosate formulation (Glifogold; Monsanto Europe, Anversa, Belgium) contained a proprietary surfactant with $360 \mathrm{~g} \cdot \mathrm{L}^{-1}$ of glyphosate in its isopropylamine salt and was applied in water at a rate of $200 \mathrm{~L} \cdot \mathrm{ha}^{-1}$.

Glyphosate was applied using a backpack sprayer (F200 Electra; Fox Motors, Poviglio, Italy) calibrated to operate at $100 \mathrm{kPa}$. Weed species were determined and the number of individual plants of each weed species within plots was counted before the glyphosate application. At Somma Lombardo, percent groundcover of weeds was $\approx 10 \%$ and the weed population consisted of $80 \%$ ( 6 plants $\left./ \mathrm{m}^{2}\right)$ annual bluegrass and $20 \%\left(2\right.$ plants $\left./ \mathrm{m}^{2}\right)$ common chickweed (Stellaria media). At Sommacampagna, percent groundcover of weeds was $\approx 5 \%$ and the main weeds were $95 \%$ ( 2 plants $/ \mathrm{m}^{2}$ ) annual bluegrass and $5 \%\left(0.5\right.$ plants $\left./ \mathrm{m}^{2}\right)$ tall fescue (Festuca arundinacea). A visual estimation of weed control efficiency was conducted $49 \mathrm{~d}$ after treatment (DAT) for the $8 \mathrm{Feb}$. application and 35 DAT for the 21 Feb. glyphosate application. Weed control was based on a scale of 0 to 100 , with $0=$ no control and $100=$ total control. Weed

Table 1. Long-term mo.ly average air temperature and precipitation from weather stations located in close proximity to the field sites in Somma Lombardo (2000-10), Sommacampagna (1993-2008), and Legnaro (1963-2007) in northern Italy.

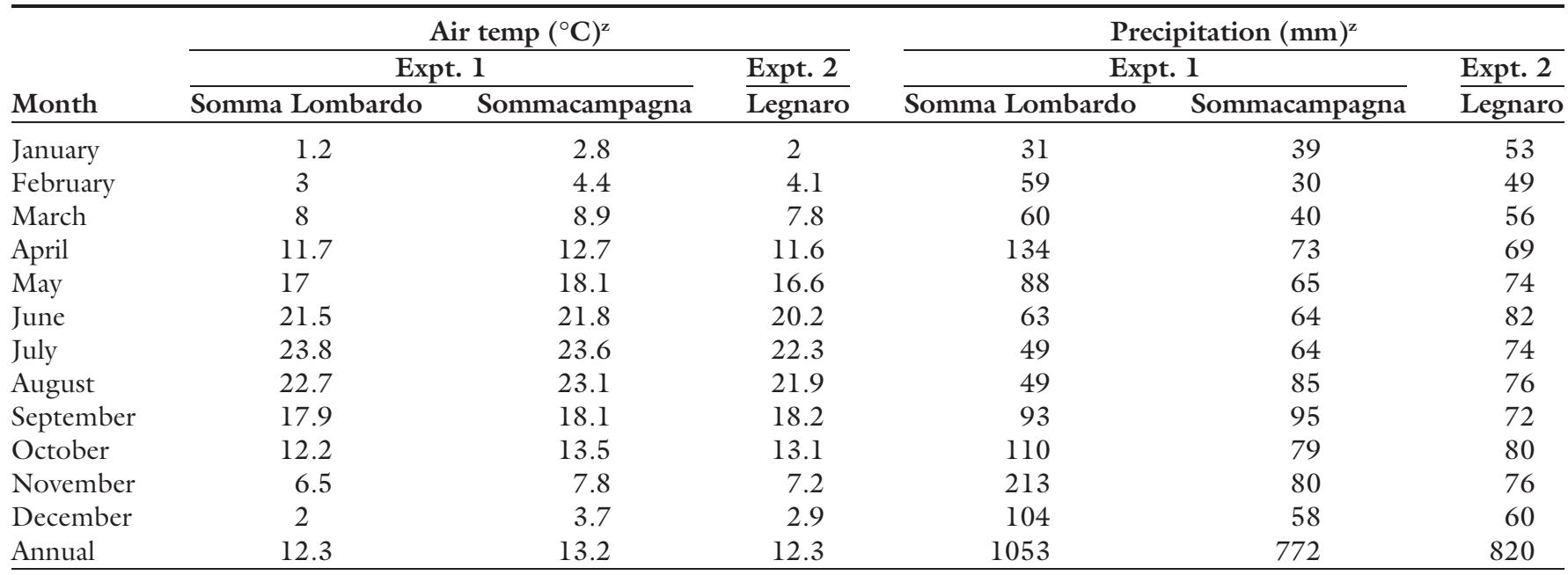

${ }^{2}\left(1.8 \times{ }^{\circ} \mathrm{C}\right)+32={ }^{\circ} \mathrm{F}, 1 \mathrm{~mm}=0.0394$ inch. 
control ratings of different species were combined to form unique values based on plant size, discoloration or necrosis, and general plant vigor (Main et al., 2004). Immediately after weed control estimations, plots were handweeded to avoid weed interference on assessments of turf regrowth.

Plots were visually assessed for spring green-up on 10 Mar., 28 Mar., 9 Apr., 15 Apr., 30 Apr., and 30 May 2011 . Spring green-up ratings were visually assessed on a linear 0 to 100 scale of the green groundcover (Munshaw et al., 2006; Patton et al., 2004). Normalized difference vegetation indices readings were also collected by means of a handheld optical sensor (Greenseeker; NTech Industries, Ukiah, CA) within $24 \mathrm{~h}$ of the visual ratings being taken (Bell et al., 2009).

EXPERIMENT 2. An additional field trial was conducted from Jan. to June 2011 at the experimental agricultural farm of Padova University in Legnaro, northeastern Italy (lat. $45^{\circ} 20^{\prime} \mathrm{N}$, long. $11^{\circ} 57^{\prime} \mathrm{E}$, elevation $8 \mathrm{~m})$. The soil at the site was a silty loam (20\% clay, 61\% silt, 19\% sand) with a $2.1 \% \mathrm{OM}, \mathrm{pH}$ of $8.3,28$ $\mathrm{mg} \cdot \mathrm{kg}^{-1} \mathrm{P}$, and $142 \mathrm{mg} \cdot \mathrm{kg}^{-1} \mathrm{~K}$. The area has a humid subtropical climate and is similar to plant hardiness zone 8 (U.S. Department of Agriculture, 1990), with the annual rainfall mostly distributed from April to November (Table 1). Grasses used in this study were 'Yukon' bermudagrass and 'Companion' zoysiagrass. The experiment was carried out on mature turf plots established in July 2005. Slow-release fertilizer $(20 \mathrm{~N}-2.2 \mathrm{P}-6.6 \mathrm{~K})$ was applied each month from May to September at a rate of $4 \mathrm{~g} \cdot \mathrm{m}^{-2} \mathrm{~N}$. Plots were mowed weekly with a rotary mower at a height of $32 \mathrm{~mm}$ with clippings removed.

On 8 Feb. 2011 (47 GDD since 1 Jan. 2011), half of the plots for each grass were treated with glyphosate at $1.1 \mathrm{~kg} \cdot \mathrm{ha}^{-1}$, using the method of application described for Expt. 1. Number of weeds and species were counted before glyphosate treatment. Percent groundcover of weeds was $\approx 12 \%$, and the main weeds were $60 \%$ ( 5 plants $/ \mathrm{m}^{2}$ ) annual bluegrass, 30\% (2 plants $/ \mathrm{m}^{2}$ ) orchardgrass (Dactylis glomerata), and $10 \%$ ( 0.8 plants $\left./ \mathrm{m}^{2}\right)$ meadow fescue (Festuca pratensis). Weed control ratings were conducted 49 DAT, following the evaluation criteria used in Expt. 1. Spring green-up ratings and NDVI readings were taken on 10 Mar.,
28 Mar., 9 Apr., 15 Apr., 22 Apr., 30 Apr., 17 May, and 30 May 2011, as described in Expt. 1. Treatments were arranged in a split-plot design with species as main plots and glyphosate treatments (treated vs. untreated) as subplots. Main plots and subplots had four replicates and measured $1.6 \times$ $4.5 \mathrm{~m}$ and $1.6 \times 2.3 \mathrm{~m}$, respectively.

Statistical analysis. Spring green-up visual ratings, NDVI readings, and weed control ratings were subjected to analysis of variance (ANOVA) $(P=0.05)$ using Proc Mixed (SAS version 9.2; SAS Institute, Cary, NC). A repeated measures procedure was used to analyze spring green-up ratings and NDVIs. A compound symmetry covariance structure resulted in the best fit for the data (lowest Akaike information criterion value) for each experiment. Fisher's protected least significant difference test was used at the $P$ level of 0.05 to identify significant differences among means. Pearson's correlation coefficients for visual ratings and NDVI readings were determined using Proc Corr (SAS version 9.2).

\section{Results and discussion}

Experiment 1. A single application of glyphosate satisfactorily controlled the weeds present, providing $98 \%$ control on average, with no differences between the two applications ( 8 and 21 Feb.) or between locations. The ANOVA of spring green-up

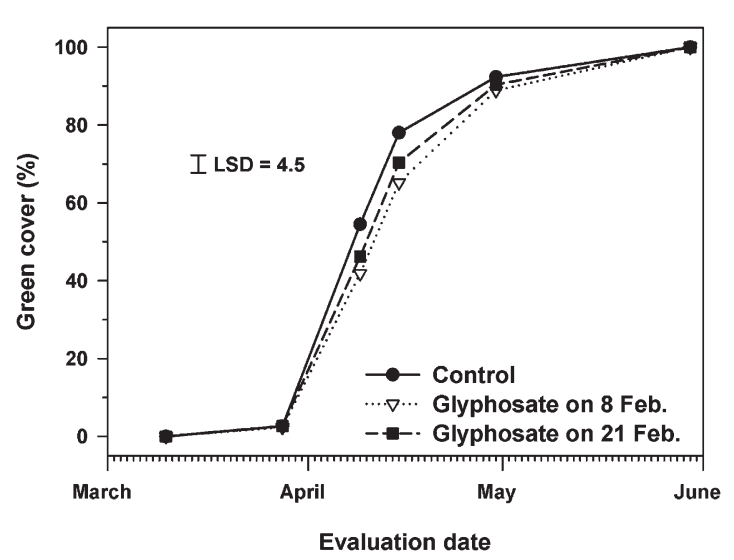

Fig. 1. Percent green cover of 'Zeon' manilagrass as affected by three glyphosate treatments [application at $1.1 \mathrm{~kg} \cdot \mathrm{ha}^{-1}(0.98 \mathrm{lb} /$ acre $)$ made on $8 \mathrm{Feb} .2011$ or 21 Feb. 2011, and control] from Mar. 2011 to May 2011. Data points represent an average of two locations and three replicates. Error bar indicates Fisher's protected least significant difference (LSD) at $P=0.05$ and can be used to determine significant differences between glyphosate treatments and evaluation dates.

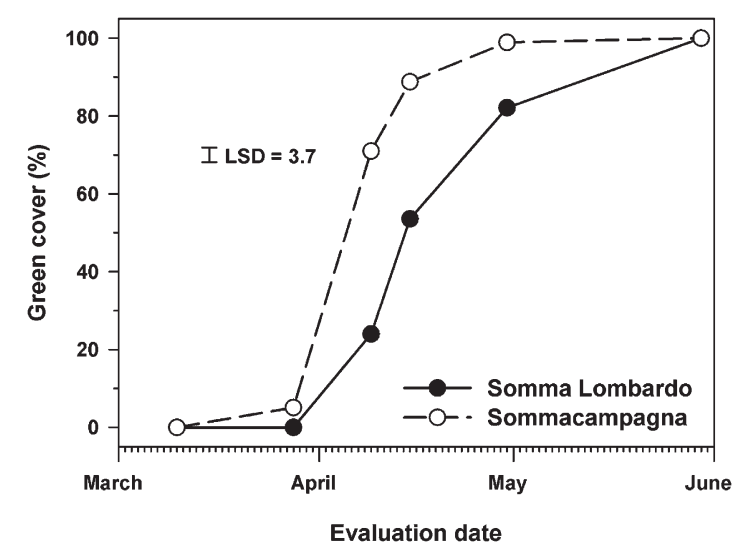

Fig. 2. Percent green cover of 'Zeon' manilagrass as affected by location in northern Italy (Somma Lombardo vs. Sommacampagna) from Mar. 2011 to May 2011. Data points represent an average of three glyphosate treatments and three replicates. Error bar indicates Fisher's protected least significant difference (LSD) at $P=0.05$ and can be used to determine significant differences between locations and evaluation dates. 
revealed significant two-way interactions between glyphosate treatment and evaluation date and between location and evaluation date. Spring green-up was also significantly affected by glyphosate treatment, location, and evaluation date. However, the interactions terms glyphosate treatment $\times$ location and glyphosate treatment $\times$ location $\times$ evaluation date were not significant; therefore, the data were pooled over glyphosate treatment or location.

When data were averaged over the locations, untreated plots had $8 \%$ to $13 \%$ more green cover than other plots on 9 and 15 Apr., with no differences between the two glyphosate applications (Fig. 1). However, all plots reached $\approx 90 \%$ green cover by the end of April and full green cover by the end of May. These results for 'Zeon' manilagrass are similar to those reported by several studies for bermudagrass, whose spring green-up was not delayed by winter applications of glyphosate (Johnson, 1976, 1977, 1980). Averaged over the three glyphosate treatments, Sommacampagna plots showed earliest spring green-up, with higher green cover than at the Somma Lombardo location from the end of March to the end of April (Fig. 2 ). These differences in speed of greenup observed between the two locations could be due to the different meteorological conditions that occurred at the two locations in March and April (Fig. 3). In Somma Lombardo there were lower minimum daily temperatures and higher monthly precipitation than in Sommacampagna, together with relatively low incident solar radiation. These differences may have led to lower temperature in the soil for Somma Lombardo compared with Sommacampagna (Hillel, 1998), which could explain the observed variation in spring green-up between the two sites (Youngner, 1959; Rimi et al., 2011). Despite the large disparity in spring green-up between locations, there was no significant interaction between glyphosate treatment and location, which suggests that the responses of glyphosate application are consistent across contrasting environmental conditions.

Responses of NDVIs to the significant interactions terms glyphosate treatment $\times$ evaluation date and location $\times$ evaluation date were consistent with those of the visual ratings (data not shown). The visual ratings of green cover were closely and positively correlated with NDVI readings collected

\section{Experiment 1}
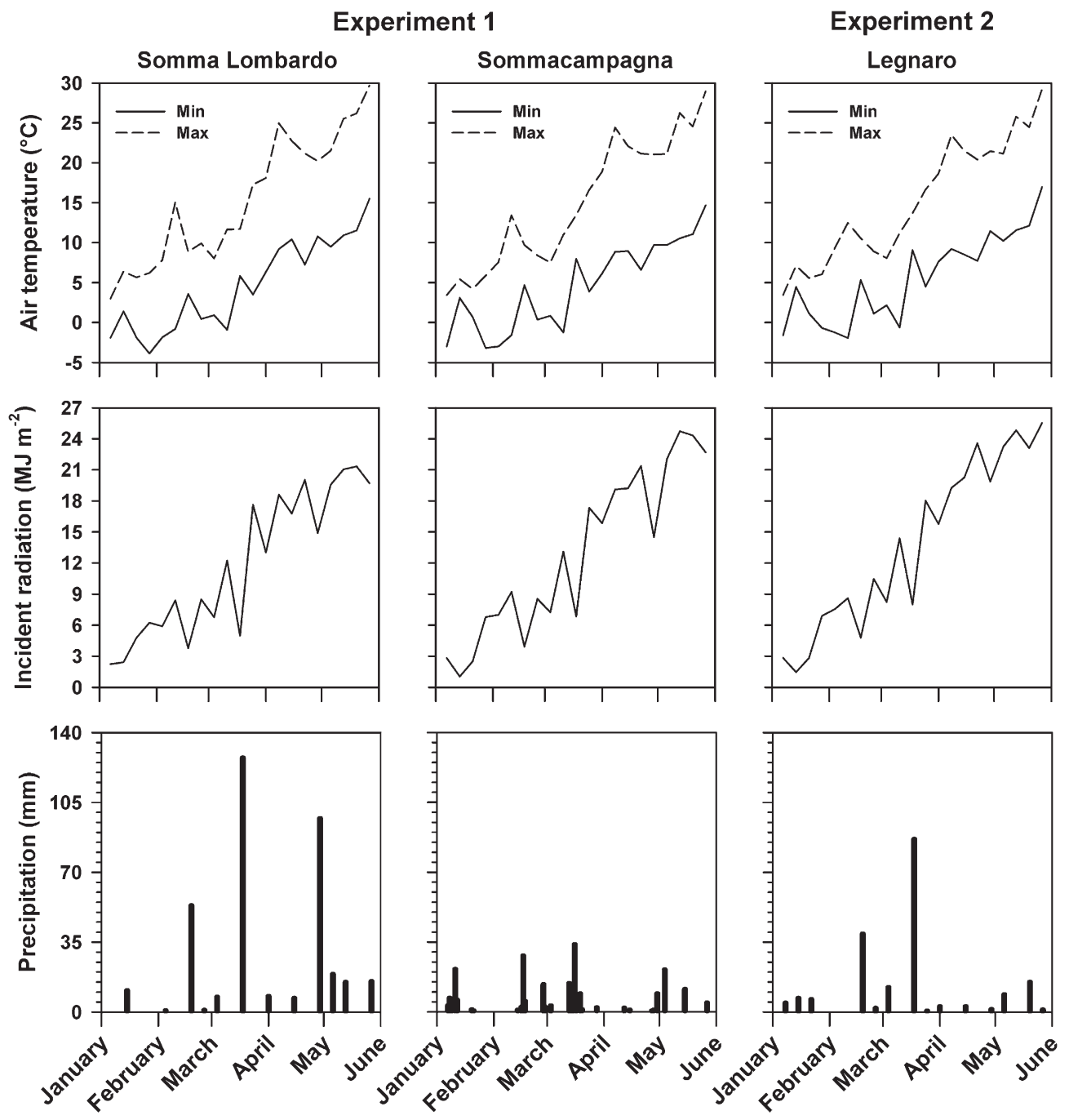

Fig. 3. Weekly maximum (Max) and minimum (Min) air temperature, incident solar radiation, and precipitation from Jan. 2011 to May 2011 collected at weather stations located in close proximity to the field sites in Sommacampagna, Somma Lombardo, and Legnaro in northern Italy; $\left(1.8 \times{ }^{\circ} \mathrm{C}\right)+32={ }^{\circ} \mathrm{F}, 1 \mathrm{MJ} \cdot \mathrm{m}^{-2}=23.9006$ langleys, $1 \mathrm{~mm}=0.0394$ inch . 
during the green-up period in both locations (Fig. 4). These results agreed with previous findings indicating that NDVI was strongly related to turf color (Bell et al., 2000, 2002). This significant correlation corroborates that NDVI could provide an unbiased estimate of turf color and potentially replace the more time-consuming visual ratings (Bell et al., 2009; Schiavon et al., 2011).

EXPERIMENT 2. The weed population present at Legnaro was controlled by winter-applied glyphosate, as was observed in Expt. 1, with 97\% control in both turf species. Results of the ANOVA of green cover data showed a significant three-way interaction among species, glyphosate treatment, and evaluation date. The interaction terms species $\times$ glyphosate treatment, species $\times$ evaluation date, glyphosate treatment $\times$ evaluation date, and all main effects were also significant.

Green cover of 'Companion' zoysiagrass was $21 \%$ lower in plots treated with glyphosate compared with controls on 9 and 15 Apr. and 12\% lower
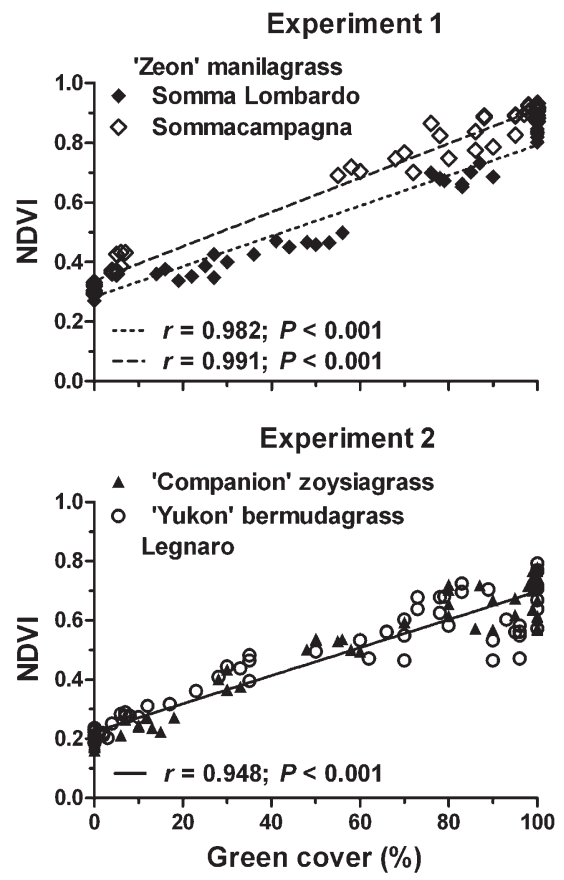

Fig. 4. Correlation between green cover visual ratings and normalized difference vegetation indices (NDVIs) during the spring green-up period (Mar. 2011 to May 2011) for 'Zeon' manilagrass in Somma Lombardo and Sommacampagna in northern Italy and for 'Companion' zoysiagrass and 'Yukon' bermudagrass in Legnaro in northeastern Italy. on 22 Apr. (Fig. 5). Compared with untreated plots, winter-applied glyphosate delayed full spring green-up of 'Companion' zoysiagrass from 22 Apr. to the end of April. Meteorological parameters in Legnaro throughout the study period were similar to those recorded in Sommacampagna (Expt. 1) (Fig. 3), where green-up of 'Zeon' manilagrass showed no delay as a result of the February applications of glyphosate (Fig. 1). Therefore, these preliminary findings suggest that the effect of winter-applied glyphosate on spring green-up could differ depending on zoysiagrasses. These results are in agreement with previous research documenting differential tolerance levels of zoysiagrass species/cultivars to other herbicides. Johnson (1978) reported that the growth of 'Meyer' zoysiagrass was less injured than 'Emerald' or 'Matrella' after applications of benefin. More recently, further tolerance differences among zoysiagrasses have been pointed out with regard to other preemergence (Johnson and Carrow, 1999) and also postemergence herbicides (Patton et al., 2006). Collectively, these findings indicate that weed control in zoysiagrasses should be tailored on the basis of varietal genetic diversity and its influence on herbicide tolerance.

Green cover of 'Yukon' bermudagrass was $5 \%$ to $10 \%$ lower in plots treated with glyphosate than in control plots throughout the April evaluation dates (Fig. 5). However, differences between treated and untreated plots were of limited economic importance since green-up was almost completed (green cover $>60 \%$ ) and no differences were observed between treated and untreated plots on 17 May and by the end of May. These data support previous studies that reported no effects on spring green-up of bermudagrass treated with glyphosate during the winter (Johnson, 1976, 1977, 1980). Time needed to achieve green-up varied greatly among species, with 'Companion' zoysiagrass completing spring green-up by the end of April, whereas 'Yukon' bermudagrass being fully green 1 month later (Fig. 5). Our findings are similar to those reported from two localities of Turkey, where zoysiagrass cultivars had faster spring green-up than bermudagrass cultivars (Severmutlu et al., 2011). Normalized difference vegetation indices responded to the different treatments similarly to visual ratings, with the significant interaction species $\times$ glyphosate treatment $\times$ evaluation date being likely related to environmental factors (data not shown). Green cover ratings were highly correlated with NDVI for both 'Companion' zoysiagrass and 'Yukon' bermudagrass (Fig. 4), as observed in Expt. 1.

\section{Conclusions}

Spring green-up of zoysiagrasses and control of winter weeds are both critically important to sod producers to optimize reestablishment planting after harvesting. Our research suggests that, under experimental conditions, glyphosate applied as a single treatment at $1.1 \mathrm{~kg} \cdot \mathrm{ha}^{-1}$ in February can effectively control winter weeds of 'Zeon' manilagrass, without injuring

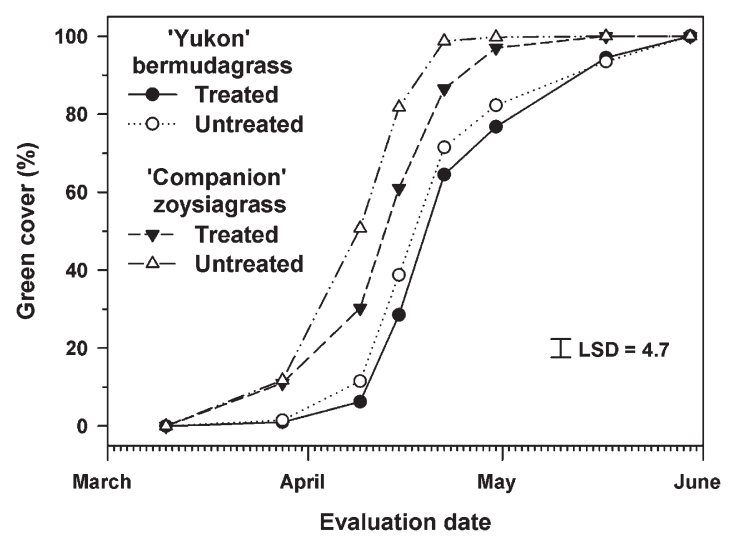

Fig. 5. Percent green cover of 'Yukon' bermudagrass and 'Companion' zoysiagrass as affected by winter application of glyphosate [treated on $8 \mathrm{Feb} .2011$ at 1.1 $\mathrm{kg} \cdot \mathrm{ha}^{-1}(0.98 \mathrm{lb} / \mathrm{acre})$ vs. control] from Mar. 2011 to May 2011. Data points represent an average of four replicates. Error bar indicates Fisher's protected least significant difference at $P=\mathbf{0 . 0 5}$ and can be used to determine significant differences between species, glyphosate treatments, and evaluation dates. 
turf in the spring. However, additional preliminary findings indicated that winter-applied glyphosate delayed spring green-up of 'Companion' zoysiagrass in a similar environment. This suggests that extending this practice to other Zoysia species/cultivars should be evaluated on a cultivar-by-cultivar basis. In addition, this study has corroborated that winter-applied glyphosate can efficiently control winter weeds without delaying spring greenup of bermudagrass turf. Our results also confirmed a strong positive correlation between visual ratings of turf green cover and NDVI measured with a handheld optical sensor.

\section{Literature cited}

Beard, J.B. 1973. Turfgrass: Science and culture. Prentice Hall, Upper Saddle River, NJ.

Bell, G.E., D.L. Martin, K. Koh, and H.R. Han. 2009. Comparison of turfgrass visual quality ratings with ratings determined using a handheld optical sensor. HortTechnology 19:309-316.

Bell, G.E., D.L. Martin, R.M. Kuzmic, M.L. Stone, and J.B. Solie. 2000. Herbicide tolerance of two cold-resistant bermudagrass (Cynodon spp.) cultivars determined by visual assessment and vehicle-mounted optical sensing. Weed Technol. 14:635-641.

Bell, G.E., D.L. Martin, S.G. Wiese, D.D. Dobson, M.W. Smith, M.L. Stone, and J.B. Solie. 2002. Vehicle-mounted optical sensing: An objective means for evaluating turf quality. Crop Sci. 42:197-201.

Breuninger, J.M. and R.E. Schmidt. 1981. Post-dormancy growth of bermudagrass as influenced by low temperatures and selected preemergence herbicides. Agron. J. 73:945-949.

Carrow, R.N. and M. Sills. 1980. Tall fescue sod production with plastic netting. HortScience 15:818-820.

Christians, N.C. 1998. Fundamental of turfgrass management. Ann Arbor Press, Chelsea, MI.

Croce, P., A. De Luca, M. Mocioni, M. Volterrani, and J.B. Beard. 2001. Warmseason turfgrass species and cultivar characterizations for a Mediterranean climate. Intl. Turfgrass Soc. Res. J. 9:855-859.
Fagerness, M.J., F.D. Yelverton, and R.J. Cooper. 2002. Bermudagrass [Cynodon dactylon (L.) Pers.] and zoysiagrass (Zoysia japonica) establishment after preemergence herbicide applications. Weed Technol. 16:597-602.

Hillel, D. 1998. Environmental soil physics. Academic Press, San Diego, CA.

Johnson, B.J. 1976. Glyphosate for weed control in dormant bermudagrass. Weed Sci. 24:140-142.

Johnson, B.J. 1977. Winter annual weed control in dormant bermudagrass turf. Weed Sci. 25:145-150.

Johnson, B.J. 1978. Response of zoysia (Zoysia spp.) and bermudagrass (Cynodon dactylon) cultivars to herbicide treatments. Weed Sci. 26:493-497.

Johnson, B.J. 1980. Postemergence winter control in bermudagrass (Cynodon dactylon) turf. Weed Sci. 28:385-392.

Johnson, B.J. 1984. Response of bermudagrass (Cynodon dactylon) turf to winterapplied herbicides. Weed Sci. 32:477-482.

Johnson, B.J. and G.D. Ware. 1978. Dates of glyphosate treatments on weeds and bermudagrass (Cynodon dactylon). Weed Sci. 26:523-526.

Johnson, B.J. and R.E. Burns. 1985. Effect of timing of spring applications of herbicides on quality of bermudagrass (Cynodon dactylon) turf. Weed Sci. 33: 238-243.

Johnson, B.J. and R.N. Carrow. 1999. Tolerance of zoysiagrass (Zoysia spp.) cultivars to preemergence herbicides. Weed Technol. 13:706-712.

Main, C.L., T.C. Mueller, R.M. Hayes, and J.B. Wilkerson. 2004. Response of selected horseweed (Conyza canadensis (L.) Cronq.) populations to glyphosate. J. Agr. Food Chem. 52:879-883.

McCalla, Jr., J., M. Richardson, D. Karcher, J. Landreth, and A. Patton. 2008. Sod production utilizing an improved seeded bermudagrass cultivar. Appl. Turfgrass Sci. doi:10.1094/ATS-2008-0118-01-RS

Mitchell, C.H. and R. Dickens. 1979. Nitrogen fertilization and mowing height effects on tensile strength of bermudagrass sod. Agron. J. 17:1061-1062.

Munshaw, G.C., E.H. Ervin, C. Shang, S.D. Askew, X. Zhang, and R.W. Lemus. 2006. Influence of late-season iron, nitrogen, and seaweed extract on fall color retention and cold tolerance of four bermudagrass cultivars. Crop Sci. 46:273-283.

Patton, A.J., G.A. Hardebeck, D.W. Williams, and Z.J. Reicher. 2004. Establishment of bermudagrass and zoysiagrass by seed. Crop Sci. 44:2160-2167.

Patton, A.J., Z.J. Reicher, A.J. Zuk, J.D. Fry, M.D. Richardson, and D.W. Williams. 2006. A guide to establishing seeded zoysiagrass in the transition zone. Appl. Turfgrass Sci. doi:10.1094/ATS-20061004-01-MG.

Rimi, F., S. Macolino, B. Leinauer, and U. Ziliotto. 2011. Green-up of seeded bermudagrass cultivars as influenced by spring scalping. HortTechnology 21 : 230-235.

Schiavon, M., B. Leinauer, E. Sevastionova, M. Serena, and B. Maier. 2011. Warmseason turfgrass quality, spring green-up, and fall color retention under drip irrigation. Appl. Turfgrass Sci. doi: 10.1094/ ATS-2011-0422-01-RS.

Severmutlu, S., N. Mutlu, R.C. Shearman, E. Gurbuz, O. Gulsen, M. Hocagil, O. Karaguzel, T. Heng-Moss, T.P. Riordan, and R.E. Gaussoin. 2011. Establishment and turf qualities of warm-season turfgrasses in the Mediterranean region. HortTechnology 21:67-81.

Tae, H.-S. 2005. Post emergence kentucky bluegrass (Poa pratensis L.) control in dormant zoysiagrass (Zoysia japonica). Proc. Amer. Soc. Agron., Crop Sci. Soc. Agron., Soil Sci. Soc. Agron. Intl. Annu. Mtg., Salt Lake City, UT, 7-10 Nov. 2005 (abstr.).

U.S. Department of Agriculture. 1990. Plant hardiness zone map. U.S. Dept. Agr., Agr. Res. Serv. Misc. Publ. No. 1475.

Velsor, S.T., J.H. Dunn, and D.D. Minner. 1989. Phytotoxicity of herbicide applications to apparently dormant zoysiagrass. Proc. VI Intl. Turfgrass Res. Conf., Tokyo, 31 July-5 Aug. 1989. p. 291-293.

Volterrani, M., N. Grossi, G. Pardini, S. Miele, M. Gaetani, and S. Magni. 1997. Warm season turfgrass adaptation in Italy. Intl. Turfgrass Soc. Res. J. 8:1344-1354.

Youngner, V.B. 1959. Growth of U-3 bermudagrass under various day and night temperatures and light intensities. Agron. J. 51:557-559. 